\title{
Atıksularda Koronavirüslerin Varlığı, Akıbeti ve Giderimi: COVID- 19 Üzerine Bir Derleme
}

\author{
Şeyma Akkurt ${ }^{1}$, Merve Oğuz \\ 1*Adıyaman Üniversitesi, Mühendislik Fakültesi, Çevre Mühendisliği Bölümü, Adıyaman, Türkiye, (ORCID: 0000-0002-0135-1975), sakkurt@ adiyaman.edu.tr \\ ${ }^{2}$ Erciyes Üniversitesi, Mühendislik Fakültesi, Çevre Mühendisliği Bölümü, Kayseri, Türkiye (ORCID: 0000-0002-8388-1477), moguz@erciyes.edu.tr
}

(Illk Geliş Tarihi 24 Ocak 2021 ve Kabul Tarihi 2 Nisan 2021)

(DOI: 10.31590/ejosat.867432)

ATIF/REFERENCE: Akkurt, Ş., Oğuz, M., (2021). Atıksularda Koronavirüslerin Varlığı, Akıbeti ve Giderimi: COVID-19 Üzerine Bir Derleme. Avrupa Bilim ve Teknoloji Dergisi, (21), 330-340.

\section{Öz}

Solunum hastalığına neden olan koronavirüs COVID-19 (SARS-CoV-2) ilk olarak 12 Aralık 2019'da Çin'in Wuhan şehrinde neden olduğu salgın hastalık sırasında tespit edilmiş̧ir ve dünyaya yayılmışırı. Sağlık uzmanları tarafindan COVID-19 üzerine yapılan araştırmalar, virüsün doğrudan yayılmasını önlemeye ve enfekte hastaları tedavi etmeye odaklanmıştır. Fakat, bazı çalışmalarda insanların dışkısında, atıksu örneklerinde virüs tespit edilmiş ve atıksu yoluyla olası bulaşma vakaları bildirilmiştir. Bu bağlamda, virüs içeren arıtılmış veya ham atıksular, arıtma çamurları, suyun tekrar kullanımı ve alıcı su ortamlarına deşarj edilmesi ikincil bulaşmaya neden olabileceği göz ardı edilmemelidir. Atıksu arıtma tesislerinin deşarj suları ve geri kazanılmış atıksular yoluyla virüsün yayılmasını engellemek için etkili bir dezenfeksiyon uygulanması bu nedenle önem arz etmektedir. Virüsün çevreye yayılmasını önlemek için atıksudan virüs giderme yöntemleri uygulanmalıdır. Bu nedenle bu çalışmada, virüsün atıksularda bulunabilirliği ve arıtımına yönelik yöntemler ele alınarak mevcut durumu hakkında bilgi verilmiştir.

\section{The Existence, Fate and Removal of Coronaviruses in Wastewaters: A Review on COVID-19}

\begin{abstract}
The coronavirus COVID-19 (SARS-CoV-2), which causes respiratory disease, was first detected on December 12, 2019, during the epidemic caused by the city of Wuhan, China, and spread to the world. Studies conducted by healthcare professionals on COVID-19 have focused on preventing the direct spread of the virus and treating infected patients. However, in some studies, viruses were detected in human feces, wastewater samples, and possible cases of contamination through wastewater were reported. In this context, it should not be ignored that treated or raw wastewater containing viruses, sewage sludge, reuse of water and discharge to receiving water environments may cause secondary contamination. Therefore, it is important to apply an effective disinfection to prevent the spread of the virus through the discharge waters and recycled wastewater of wastewater treatment plants. To prevent the virus from spreading to the environment, virus removal methods from wastewater should be applied. Therefore, this research offered details about the current situation by taking into account the availability and treatment of the virus in wastewater.
\end{abstract}

Keywords: Coronavirus, COVID-19, Wastewater, Disinfection, Sewage, Removal. 


\section{Giriş}

Solunum yolu rahatsızlığına yol açan COVID-19 virüsü (SARS-CoV-2), ilk kez Çin'in Wuhan kentinde yol açtığı salgın hastalık sırasında 12 Aralık 2019 tarihinde tespit edilmiş olup ardından tüm dünyaya yayılmıştır (TOBSYGM, 2020). Koronavirüsler (CoVs) hayvanlar1 ve insanlar1 enfekte edebilen büyük bir virüs ailesinin bir parçasıdır. Zarf adı verilen yağlı bir protein tabakası ile çevrili olan koronavirüsler, büyük, pozitif polariteli, yüzeyinde protein çıkıntıları olan tek iplikli RNA virüsleridir (Ak, 2020). Koronavirüs genotipik ve serolojik özelliklerine göre Alfa, Beta, Gama ve Deltakoronavirüs olmak üzere dört farklı gruba ayrılmaktadır (Lu ve ark., 2015). Alfa ve beta koronavirüs insanları enfekte edebilirken, gama ve delta koronavirüs sadece hayvanları enfekte edebilmektedir (Ak, 2020; Lu ve ark., 2015). Kaynağı yarasalar olan, ciddi akut solunum sendromu (SARS CoV) ve Orta Doğu solunum sendromu (MERS CoV) virüslerinin ara konakçıları ise çöl devesi ve misk kedileridir (Petrosillo ve ark., 2020). COVID-19 virüsü ise 2019 yılı Aralık ayından bu yana küresel bir salgına neden olan daha önce insanda rastlanmayan bir koronavirüstür (Ak, 2020).

COVID-19 virüsü tespit edilen 41 vakanın üçte ikisinin Huanan (Wuhan, Çin) deniz ürünleri pazarında aynı zamanlarda bulunduğu ve virüsün pazardan başladığ 1 tespit edilmiştir (Chen, 2020). Huanan deniz ürünleri pazarında çeşitli canlı yabani hayvanlar satılmaktadır (Shereen ve ark., 2020). COVID-19 virüsünün gen dizilimi, virüs gen dizilim veri bankasındakilerle karşılaştırılması sonucunda en çok benzeyen gen dizilimlerinin $\% 88$ oranında yarasalardan kaynaklanan iki koronovirüse ait olduğu belirlenmiştir. Bunun üzerine bilim insanları koronovirüsün yarasalardan kaynaklanabileceğini düşünmüştür. Ancak COVID-19 virüsünün başladığı Huanan deniz ürünleri pazarında yarasa satılmıyordu. Yarasa satılmadığından dolayı, virüsün insanlara iletilmesinde henüz tanımlanmamış başka bir hayvanın bir tür ara taşıyıcı olduğu kanısına varılmıştır (Ak, 2020). Şekil 1'de koronavirüsün yapısı gösterilmiştir (Aka Biyoteknoloji, 2020).

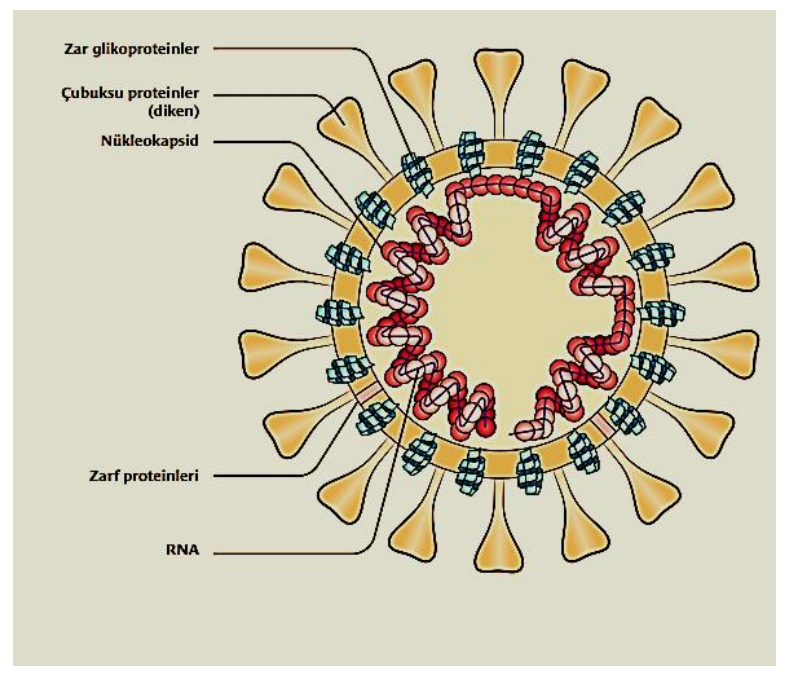

Şekil 1. Koronavirüsün yap1sı (Aka Biyoteknoloji, 2020).

Yapılan araştırmalar sonucunda COVID-19 virüsü tespit edilen vakalardan bazılarının Huanan (Wuhan, Çin) deniz ürünleri pazarına gitmeyen kişiler olduğu tespit edilmiştir. Bu durum virüsün insandan insana bulaştığını göstermiştir.
WHO tarafından 11 Mart 2020 tarihinde küresel salgın ilan edilmiştir (A ğdıç vd., 2020). Virüsün insandan insana aktarıldığ1 bilinmektedir. COVID-19 virüsünün ana bulaşma yolları solunum damlacıkları ve doğrudan temastır. Enfekte bir kişiyle yakın temasta olan herkes potansiyel olarak enfektif solunum damlacıklarına maruz kalma riski altındadır. Damlacıklar ayrıca virüsün yaşayabileceği yüzeylere de inebilir; böylece enfekte olmuş bir bireyin yakın çevresi bulaşma kaynağı olarak kullanılabilir (WHO, 2020). Yani kontamine yüzeyler ve nesneler ile temas sonucunda da virüs başka insanlara da bulaşabilmektedir (TOBSYGM, 2020). Fakat, enfekte bir kişinin dışkısından COVID-19 virüsünün bulaşma riskinin düşük olduğu düşünülmektedir (CDC, 2020). Mevcut kanttlar, enfeksiyöz COVID-19 virüsüne yakalanan hastalarda görülen semptomların; ateş, kuru öksürük, kas ağrısı, yorgunluk ve ishal gibi hastanın yaşına göre değişiklik göstermektedir (Zhang ve ark., 2020). Virüsün ishal veya bağırsak enfeksiyonu belirtilerine bakılmaksızın dışkıyla atılabileceği düşünülmektedir (WHO, 2020). Enfekte olan bazı hastalarda, enfeksiyonun erken evrelerinde ishal görülmesi üzerine hasta dışkısında yapılan ölçümlerde COVID-19 tespit edilmiştir. Bunun üzerine Su Çevre Federasyonu (WEF) tarafindan, COVID-19 virüsünün fekal-oral yoldan bulaşabileceği ifade edilmiştir (WEF, 2020).

$\mathrm{Bu}$ çalışmada, atıksuda koronavirüslerin varlığı, virüslerin atıksudaki akıbeti, atıksu arıtımı sırasında hayatta kalmaları ve giderimleri tartışılmıştır. Virüsün bulaşma riski geri kazanılmış suların yeniden kullanılması (park, bahçe sulama ve proses suyu) perspektifinden de değerlendirilmiştir. Ayrıca atıksu arıtıma tesisleri (AAT) çalışanları ve halk sağlığı açısından potansiyel enfeksiyon riskleri de incelenmiştir. Alt başlıklarda COVID-19 virüsünün atıksulardaki durumu hakkında detaylı bilgiye yer verilmiştir.

\section{Atıksularda Koronavirüslerin Varlığı}

Atıksuda virüs oluşumuna ilişkin çalışmaların çoğu, adenovirüsler, çocuk felci virüsleri, enterovirüsler, norovirüsler ve rotavirüsler gibi gelişmemiş enterik virüslere odaklanmıştır (Ye ve ark., 2016; Fumian ve ark., 2010; Katayama ve ark., 2008). Bunun temel nedeni, bunların esas olarak fekal-oral yoldan iletilmesidir (Ye ve ark., 2016). Bununla birlikte, atıksuda koronavirüsler gibi zarflı virüslerin varlığı, suda hayatta kalma ve dağılım davranışlarındaki farklılıklar nedeniyle büyük ölçüde değişiklik gösterebilmektedir (Arbely ve ark., 2006; Ye ve ark., 2016). Atıksulardan alınan numunelerde koronavirüsün doğru ölçümü oldukça zor olup, bu konuda çok az araştırma yapılmıştır (Amoah ve ark., 2020). Önceki araştırmalar, standart virüs konsantrasyon yöntemlerinin, çevresel su örneklerinden zarflanmış virüsleri geri kazanmada yetersiz olduğunu göstermiştir (Haramoto ve ark., 2009). Atıksudaki koronavirüslerin ilk tespitlerinden biri 2013 yılında gerçekleştirilmiştir (Wong ve ark., 2013).

Bir çalışmada zarflanmamış enterik virüsler üzerine araştırma yapılmıştır. ABD'de 12 aylık boyunca DNA ve RNA virüslerinin tespiti üzerine rapor edilmiştir ve mikrodiziler kullanan 12 numunenin birinde koronavirüsler atıksuda bulunmuştur. Aynı yıl, viral metagenomik bir araştırmada, atıksudaki koronavirüs varlığına kanıt sağlayan CoV HKU1 genomunu (soğuk algınlığı CoV) tespit edilmiştir (Bibby ve Peccia, 2013). Daha yakın tarihli bir çalışmada ise, Suudi Arabistan'da yüzey suyunda Alphacoronavirus cinsine ait hayvan koronavirüsünün moleküler tespiti yapılmıştır (Blanco ve ark., 2019). Koronavirüsün özellikle insan dışkısı ile 
kanalizasyon sistemine karıştığı bilinmektedir (Amoah ve ark., 2020). COVID-19 teşhisi konan bazı hastaların dışkılarında COVID-19 virüsü bulunmuştur ancak, yalnızca viral-RNA'nın saptanması, canlı virüsün varlığını ve Covid-19'un fekal-oral yolla bulaştığına dair doğrulanmış bir rapor bulunmamaktadır. Ancak, SARS koronavirüsünün dışkı ile bulaştığına dair bir kanıt bulunmaktadır (CDC, 2020). 2003 yılında, Hong-Kong'da 50 katlı bir binada sihhi tesisattaki ve havalandırma sistemindeki sorunlar nedeniyle SARS koronavirüsü başka dairelere taşınarak bina içinde yayılmasına neden olduğu tespit edilmiştir. Binada virüsün yayılması, 342 kişinin enfekte olmasına ve 42 kişininin de ölümüne yol açmıştır. Virüsün diğer dairelere yayılmasının nedeni olarak banyolarda suyu boşalmış sifonlar ve doğru projelendirilmemiş havalandırma sistemlerinin neden olabileceği belirtilmiştir. Ancak virüsün oral yolla mı veya aerosolların solunması yoluyla mı yayıldığı bilinmemektedir (WHO ve FAO, 2020). Bu nedenle COVID-19 virüsünün apartmanlarda yayılmasında arızalı tuvaletlerin ve havalandırma sistemi hatalarının olası risklerden olabileceği belirtilmiştir. Şekil 2'de virüsün sıhhi tesisat ve havalandırma hataları nedeniyle başka dairelere taşınımı gösterilmiştir (Medema ve ark., 2020).

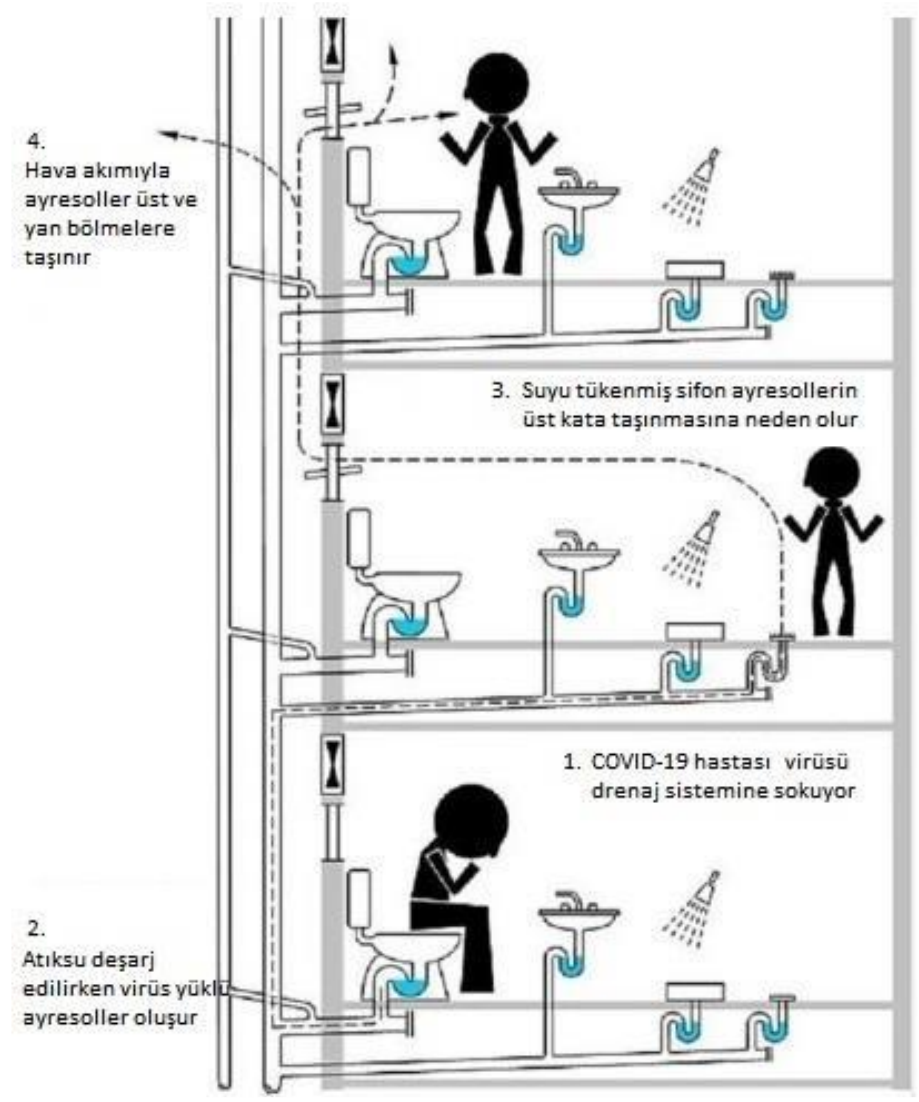

Şekil 2. Virüsün sıhhi tesisat ve havalandırma hataları nedeniyle başka bölmelere taşınımı

Virüsün sıhhi tesisat ve havalandırma sistemlerindeki zayıflık nedeniyle yayılmasını engellemek için WHO, standart atıksu arıtma ile birlikte kapalı banyo drenajları, havalandırma sistemine aerosol haline gelmiş dışkının kaçmasını engelleyen geri akış vanaları bulunan bakımlı sistemlerin kullanılmasını önermektedir (WHO, 2020). Bu çalışma ile koronavirüslerin atıksulardaki varlığının saptanmasına olan ilgi artmıştır. Atıksuda koronavirüs oluşumuna olan ilginin artmasının bir başka nedeni ise; atıksu bazlı epidemiyolojidir (WBE). WBE, enfeksiyonun varlığını ve ölçeğini anlamak için atık suyun bir gösterge olarak kullanılabilen bir kavram olup, yasa dışı alkol, uyuşturucu, tütün tüketimi, ilaç kullanımı/kötüye kullanımı, su kirliliği vb. belirlenmesi için kullanılmaktadır. Böylece belirli biyobelirteçler izlenerek nüfusun alışkanlıkları tespit edilerek erken müdahale edilebilmektedir (Mao ve ark., 2020). Covid-19 vakaları bildirilmeden önce kanalizasyon örneklerinde tespit edilerek, vakaların sağlık kuruluşlarında belgelenmeden önce virüsün atıksuda sürekli izlenerek tespit edilebileceği belirlenmiştir (Medema ve ark., 2020). Viral RNA, hastalığın başlangıcından haftalar önce dışkıda ve ardından atıksuda tespit edilebildiğinden, bu kavram hastalık salgını için erken uyarı sistemi olarak kullanılabilir (Xagoraraki ve O'Brien, 2020). SARS-CoV-2'nin WHO tarafindan 11 Mart 2020'de dünya çapında yayılan salgının duyurulmasının ardından, atıksu bazlı epidemiyoloji birçok ülkede büyük ilgi görmüştür: Hollanda (Medema ve ark., 2020), ABD (Wu ve ark., 2020), Avustralya (Ahmed ve ark., 2020), Fransa (Wurtzer ve ark., 2020), Çin (Wang ve ark., 2020), İspanya (Randazzo ve ark., 2020), İtalya (La Rosa ve ark., 2020; Rimoldi ve ark., 2020) ve İsrail (Bar Or ve ark., 2020), atıksularda farklı virüs konsantrasyon teknikleri kullanarak analizler gerçekleştirmiştir. Aşağıda bu çalışmalara bazı örnekler verilmiştir.

Medema ve ark.'nın (2020) yaptığ çalıșmada, Hollanda'nın yedi şehrindeki iki kanalizasyon sisteminden alınan numunelerde COVID-19 virüsü tespit edilmiştir.

Balboa ve ark. (2020) çalışmalarında, birincil ve ikincil arıtılmış atıksu ve çamur örnekleri İspanya'nın kentsel AAT'den alınmıştır. Gerçek zamanlı RT-PCR ile SARS-CoV-2 varlığı araştırılmıştır. Çalışmada, SARS-CoV-2 partikülleri çamur tarafından tutulması nedeniyle atıksu içinde tespit edilememiştir. Sonuç olarak, çamur yoğunlaştırıcı daha yüksek katı konsantrasyonu (daha fazla virüs parçacığı) ve daha uzun bekleme süresi sayesinde SARS-CoV-2 parçacıklarını tespit etmek için uygun bir ünite olduğu görülmüştür.

Kocamemi ve ark.'nın (2020) çalışmasında, Türkiye'deki COVID-19 vakalarının yaklaşı \%65'ine sahip olan İstanbul'un AAT'lerindeki virüs konsantrasyonunu tespit etmek için çalışmalar yapılmıştır. İstanbul'un yedi büyük belediyesinin AAT girişinden, birincil ve atık aktif çamurdan numuneler alınarak SAR-CoV-2 seviyelerini araştırmışlardır. ABD tarafından doğrulanan gerçek zamanlı RT-PCR teşhis paneli ile yapılan analizde tüm numunelerin sonucu pozitif çıkmıştır. SARS-CoV-2, litre başına $1,17 \times 10^{4}$ ila $4,02 \times 10^{4}$ arasında değişen kopyalar tespit edilmiştir. Çamurdaki SARS-CoV-2 hakkındaki bilgiler, çamur susuzlaştırma, stabilize etme ve bertaraf işlemlerinin uygulanmasında faydalı olacağı ifade edilmiştir. Su ortamlarındaki koronavirüslerin tespit edilmesi ile ilgili çalışmalar Tablo 1'de gösterilmiştir. Koronavirüslerin doğada hayatta kalmaları, atıksuda oluşumlarını etkileyen önemli faktör olabileceği düşünülmektedir. Bilim insanları arasındaki yaygın görüş, koronavirüslerin doğada sadece birkaç gün yaşayabileceği yönündedir, ancak bazı çalışmalarda bu düşünceyi çürüten bulgular elde edilmiştir (Amoah ve ark., 2020; Kampf ve ark., 2020). Laboratuvar ortamında yapılmış olan bir çalışmada, koronavirüslerin insan dışkısı ile kontamine olmuş sularda yaklaşık dört hafta boyunca enfekte edici özelliklerini sürdürdüğü belirlenmiştir (Casanova ve ark., 2009). $\mathrm{Bu}$ durumun nedeni olarak, virüsün insan bağırsak sisteminde tekrar çoğalmasının bir sonucu olabileceği düşünülmüştür (ÇMO,2020). 
Tablo 1. Su ortamlarındaki koronavirüs tespit çalışmaları

\begin{tabular}{|c|c|c|c|c|}
\hline Virüs & Örnek & Tespit Metodu & Ülke & Referans \\
\hline $\begin{array}{l}\text { Alfakoronavirüs } \\
\text { Betakoronavirüs }\end{array}$ & Yüzey suyu & RT-qPCR & $\begin{array}{l}\text { Suudi } \\
\text { Arabistan }\end{array}$ & (Blanco ve ark., 2019) \\
\hline SARS-CoV-2 & Kanalizsyon & RT-qPCR & Hollanda & (Medema ve ark., 2020) \\
\hline SARS-CoV-2 & Atıksu & RT-qPCR & Avustralya & (Ahmed ve ark., 2020) \\
\hline SARS-CoV-2 & Arıtılmamış ve arıtılmış atıksu & RT-qPCR & Fransa & (Wurtzer ve ark., 2020) \\
\hline SARS-CoV-2 & Atıksu & RT-qPCR & Hollanda & (Lodder ve ark., 2020) \\
\hline SARS-CoV-2 & Atıksu & RT-qPCR & İspanya & (Randazzo ve ark., 2020) \\
\hline SARS-CoV-2 & Birincil çamur & RT-qPCR & $\mathrm{ABD}$ & (Peccia ve ark., 2020) \\
\hline SARS-CoV-2 & Atıksu ve nehir & $\begin{array}{l}\text { RT-qPCR ve tüm } \\
\text { genom dizileme }\end{array}$ & İtalya & (Rimoldi ve ark., 2020) \\
\hline SARS-CoV-2 & Birincil ve atık aktif çamur & RT-qPCR & Türkiye & $\begin{array}{l}\text { (Alpaslan Kocamemi ve ark., } \\
\text { 2020) }\end{array}$ \\
\hline
\end{tabular}

\subsection{Koronavirüslerin Atıksudaki Akıbeti ve Hayata Kalması}

Son zamanlarda yapılmış olan çalışmalara göre, SARS-CoV ve MERS-CoV'in farklı çevresel koşullar altında hayatta kaldığını gösteren kanıtlar bulunmaktadır. Atıksudaki SARSCoV RNA’sının ilk raporları, 2003 salgını sırasında Pekin'de SARS hastalarını kabul etmek için belirlenmiş hastaneler olan Xiao Tang Shan hastanesi ve PLA'nın 309. hastanesinde yürütülen çalışmalarda elde edilmiştir. Koronavirüs atıksularda, sıcaklığa ve katı madde miktarına bağlı olarak canlılığını birkaç saatten birkaç güne kadar sürdürebilmektedir. Yapılan incelemelerde, koronavirüsün ham atıksuda $20{ }^{\circ} \mathrm{C}$ 'de 2 gün, 4 ${ }^{0} \mathrm{C}^{\prime}$ de ise 14 gün varlığını koruduğu belirlenmiştir. Klasik Aktif Çamur Prosesinden oluşan biyolojik arıtma sistemi çıkış suyunda SARS korona virüsüne rastlanmamıştır. Ancak atıksuda bulunan askıda katı maddelerin (AKM) virüse koruma sağladığı tespit edilmiştir. $\mathrm{Bu}$ nedenle koronavirüsün; ham atıksuda varlığını ön arıtmadan geçmiş atıksuya göre, daha fazla koruyabildiği saptanmıştır (Wang ve ark., 2005).

Gundy ve ark.'nın (2009) yapmış oldukları çalışmada, atıksudaki koronavirüsün $20^{\circ} \mathrm{C}$ 'de $\% 99,9$ oranında azalmasının 2-3 gün süreceğini bildirmiştir.

Ye ve ark.'nın (2016) çalışmasında, fare hepatit virüsü (MHV) pastörize edilmemiş atıksularda \%90 inaktivasyonun 13 $( \pm 1)$ saat sürdüğünü gözlemlemiştir.

Diğer taraftan Casanova ve ark. (2009) tarafindan yapılan çalışmada ise bulaşıcı gastroenterit virüsünün (TGEV) atıksudaki \%99 oranında gideriminin bir hafta sürdüğü ileri sürülmüştür. Deneyler, atıksudaki diğer mikropların olası etkilerini ortadan kaldırmak için pastörize su kullanılarak yapılmıştır (Amoah ve ark., 2020).
Rimoldi ve ark (2020), yapmış oldukları çalışmada, hücre kültürlerine dayalı olarak atıksuda canlı SARS-CoV-2 olmadığını tespit etmiştir. Başka bir çalışmada ise, virüsün dışkı ile atılmasından atıksu örnekleme noktasına ulaşmasının 6-8 saat sürdüğü ifade edilmiştir. Bu nedenle virüsün bu süre içinde inaktive olmuş olabileceği ileri sürmüşlerdir (Zhang ve ark., 2020; Chan ve ark., 2004).

Sonuç olarak; diğer koronavirüslerden elde edilen verilere ve dışkıda canlı SARS-CoV-2 viral partiküllerinin oluşumuna dayanarak, arıtılmamış atıksu bazı canlı ve bulaşıcı insan koronavirüslerini içerebileceği ifade edilmiştir (Zhang ve ark., 2020; Chan ve ark., 2004; Xu ve ark., 2005).

\subsubsection{Atıksuda Koronavirüsün Hayatta Kalmasını Etkileyen Faktörler}

Atıksu ortamlarında koronavirüslerin hayatta kalmasını virüs yapısı, sıcaklık, atıksu karakteristiği ve pH gibi fizikokimyasal faktörler etkilemektedir (Amoah ve ark., 2020). WHO tarafından yapılan açıklamada, SARSCoV-2'nin atıksu veya içme suyunda hayatta kaldığına dair hiçbir kanıt olmadığını ileri sürülmüştür. Muhtemelen zarflı koronavirüslerin çevresel koşullara (klor, pH ve sicaklık vb.) daha duyarlı olduğu tahmin edilmektedir (WHO, 2020). Bu nedenle, konvansiyonel atıksu arıtma prosesleri SARS-CoV-2'yi inaktive etmelidir ve içme suyu arıtma tesislerinde kullanılan çoklu bariyerler SARS-CoV2'yi tespit edilemeyen ve düşük risk seviyelerine $(<4-10$ yillık risk) indirmek için yeterli hale getirilmelidir.

Casanova ark.'nın (2009) yaptıkları çalışmada, reaktif sınıfı suda TGEV'de $4 \log (\% 99,99)$ azalma için 44 gün ve $25^{\circ} \mathrm{C}$ 'de MHV için 35 gün süreceğini bildirmişlerdir. Pastörize atıksuda, aynı koşullarda aynı inaktivasyonu TGEV için 19 gün ve MHV için 14 gün süreceği bulunmuştur. 
Ayrıca atıksuda yaygın olan çözünmüş maddelerin yüksek moleküler ağırlığının virüslerin hayatta kalmalarını etkileyebileceği ileri sürülmüştür (Noble ve Fuhrman, 1997). Wang ve ark. (2005) yaptığı çalışma da bu görüşü desteklemektedir.

\subsubsection{Kullanılmış Suların Tekrar Kullanımında COVID-19 Virüsünün Bulaşma Riski}

Kullanılmış sular; birçok alanda tarım ve yeşil alanları sulama, proses suyu olarak endüstriyel amaçlı kullanım, rekreasyonel ve çevresel amaçlarla kullanım, içme suyu amaçlı olmayan kentsel kullanım, yeraltı suyu besleme, doğrudan ve dolaylı olarak içme suyu amacıyla kullanılmaktadır (Duman, 2017). Kullanılmış suların yeniden kullanımı sayesinde su kaynaklarının korunması, kıyısal kirliliğin önlenmesi, tarım arazilerinin arıtılmış atıksu ile sulanmasıyla; tarımda kullanılan su ve gübre miktarının azalmasını ve içme suyu olarak kullanılacak yüksek kalitedeki suların kullanımını engelleyerek içme suyu arıtma tesisine ve şebekeye olan yükün azalmasını sağlamaktadır (Duman, 2017).

Dünyadaki atıksuların \%80'inin arıtılmadan su kaynaklarına ulaştığı düşünülürse, içme suyu amacıyla dolaylı kullanım da dahil olmak üzere plansız yeniden kullanımların bilinenden çok daha yaygın olduğu anlaşılmaktadır. WHO'nun 1989 yılında yayınladığı rehber doküman, kullanılmış suların yeniden kullanılması konusundaki pek çok mevzuatın oluşturulmasında referans olarak kullanılmaktadır (TOBSYGM, 2020). WHO tarafindan bu konuda hazırlanan dokümanlar, suyun farklı yeniden kullanım amaçlarına odaklanmıştır ancak, ortak noktaları halk sağlığını ilgilendiren konularda güvenli bir yaklaşım getirmeyi hedeflemeleridir. Risk değerlendirmesi, epidemiyolojik çalışmalar, sudan kaynaklanan salgın hastalıklarla ilgili veriler gibi pek çok çalışma neticesinde genel bir çerçeve çizilebilmiş böylece etkili, uygulanabilir, güvenilir standartlar ve rehber dokümanlar geliştirilebilmiştir. WHO'nun ürettiği rehber dokümanlardaki temel yaklaşım mikrobiyolojik kontaminasyonun ve buna bağlı olarak gerçekleşebilecek hastalıkların önüne geçmektir. $\mathrm{Bu}$ anlamda atıksuların doğru şekilde arıtıldığından, dezenfekte edildiğinden ve bu sular ile temas riski bulunan kişilerin hijyen ile ilgili önlemleri aldıklarından emin olunması durumunda ayrıca koronavirüs ile ilgili önlemlerin alınmasına ihtiyaç bulunmadığ düşünülmektedir (TOBSYGM, 2020). Kullanılmış sular, yaygın olarak tarımsal sulama ve peyzaj sulama faaliyetlerinde yeniden kullanılmaktadır. İnsanların arıtılmış kullanılmış suya maruz kalma riski tercih edilen sulama tekniğine göre farklılık göstermektedir. Yağmurlama sulama, yapıldığında kullanılmış sularda bulunan kirleticiler toprağa, sulanan ürünlerin yüzeyine ve zararlı patojenleri taşıyan aerosoller yoluyla yerleşim yerlerine kadar taşınabilmektedir (CDC, 2021).

WHO tarafindan yayınlanan 23 Nisan 2020 ara rehberinde atıksuyun güvenli bir şekilde yönetilmesinin önemi üzerinde durulmuştur. COVID-19'un çevreye yayılmasının sınırlandırılması, hali hazırda birkaç hayvanın potansiyel konakçı olarak tanımlandığı ve geri kazanılan suyun sulamada kullanılabileceği düşünüldügünde büyük önem taşıdığı ifade edilmiştir (WHO, 2020). Gerba ve ark. (2017), AAT'lerden geri kazanılmış suyun kullanımına bağlı olarak sağlaması gereken virüs azaltma faktörünün olması gerektiğini bildirmişlerdir. Yenilebilir mahsullerin sulanması için, 6 log gideriminin yeterli olduğunu gösterirken, suyu içilebilir hale getirmek için $12 \log$ gideriminin gerekli olduğu ifade edilmiştir. Aynı giderim hedefleri Ahmed ve ark. (2020) tarafindan da bildirilmiştir.

Bir çalışmada, çiğ olarak tüketilen marul ve çilekte bazı koronavirüs türlerinin varlığ 1 araştırılmıştır. Virüsler çilekteki numunelerden çoğaltılamazken maruldan alınan numunelerde çoğalmıştır. Bu nedenle, ikincil bulaşma riskini önlemek için, hükümetler tarafından gerekli önlemler alınmalıdır (Gawlik ve ark., 2020).

Türkiye'de atıksular; park, bahçe sulama ve proses suyu olarak tekrar kullanılmaktadır (Duman, 2017). İstanbul'da AAT çıkış sularının bir kısmı peyzaj amaçlı bitkilerin sulanmasında kullanılmaktadır. Anadolu'da ise bazı yerleşim yerlerinde, kanalizasyondan doğrudan alınan atıksular sulama amaçlı kullanılmaktadır (ÇMO, 2020). Özellikle herhangi bir arıtım işlemine tabi tutulmayan veya verimli olarak arıtımı yapılmamış AAT çıkış suları virüslerin insana taşınmasında önemli risk oluşturmaktadır. Özellikle sulama işleminin fiskiyeler ile yapılması nedeni ile sulama suyunda bulunan virüsler kolaylıkla ortama yayılabilmektedir. Bu durum halk sağlığı için tehlike oluşturmaktadır (Medema ve ark., 2020).

\section{Atıksuların Aritımı Sırasında Koronavirüslerin Giderimi}

Konvansiyonel AAT prosesleri esas olarak organik madde ve AKM uzaklaştırılması için tasarlanmıştır (Droste ve Gehr, 2017). Bununla birlikte, her bir proseste belli bir seviyeye kadar patojen giderimi elde edilmektedir, ancak bu prosesler esas olarak virüslere göre bakteriler üzerinde daha etkilidir (Dias ve ark., 2018; Sinton ve ark., 2002). Buna ek olarak, konvansiyonel AAT'ler genellikle virüsleri tamamen ortadan kaldırmaz ve pandemiler sırasında yüksek düzeyde etkili viral yükler, deşarj öncesinde virüslerin yeteri kadar giderilmemesine neden olabilir. Tatlı su kaynaklarının azalması nedeniyle; arıtılmış atık sular, yeraltı suyunun doldurulması, gıda mahsullerinin rekreasyonu ve sulanması, kentsel kullanım (park, bahçe sulanması, proses suyu vb.) gibi farklı amaçlarla tekrar kullanılmaktadır. Bu durum Covid-19'un iletimi için başka potansiyel yollar oluşturmaktadır (Bogler ve ark., 2020). Şekil 3'te Covid-19'un atıksu kaynaklı olası bulaşma yolları verilmiştir (Bhatt ve ark., 2020).

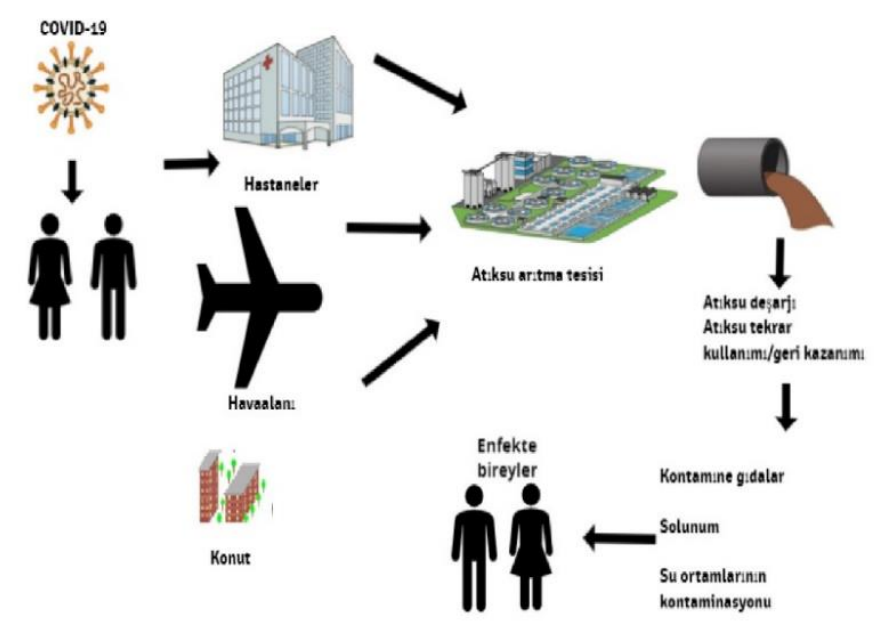

Şekil 3. Covid-19'un atıksu kaynaklı olası bulaşma yolları (Bhatt ve ark., 2020). 
Aktif çamur sistemleri, dünya genelinde yaygın olarak kullanılan atıksu arıtma prosesidir (Kitajima ve ark., 2014; Nordgren ve ark., 2009). Bu arıtma prosesi; birincil çökeltme, biyolojik bozunma ve ikincil arıtmayı içermektedir (Sidhu ve ark., 2018; Keegan ve ark., 2013). Genel olarak, ikincil atıksu arıtım1, 1-log (\%90) virüsleri ortalama olarak yok etme kapasitesine sahiptir, ancak virüs giderme seviyesi oldukça değişkendir, ihmal edilebilir seviyeden 2-log'dan fazlasına kadar (\%99) değişiklik göstermektedir (McLennan ve ark., 2009). Bu değişkenlik nedeniyle, atıksu arıtmada virüslerin inaktivasyonu için birincil süreç kimyasal veya radyasyon dezenfeksiyonu olması gerektiği yapılan çalışmalarda ifade edilmiştir (Kataki ve ark., 2021).

Atıksuda koronavirüsle mücadeleye acil bir yanıt olarak çoğu ülkede, mevcut uygulamalara göre arıtılmış atıksuyun dezenfekte edilmesine devam etmeleri için atıksu yönetimi kurumları tarafından yönergeler yayınlanmaktadır. ABD Mesleki Güvenlik ve Sağlık İdaresi (OSHA) tarafindan Şubat 2020'de yayınlanan atıksu işçi rehberinde, AAT'lerde kullanılan mevcut dezenfeksiyon yöntemlerinin (hipokloröz asit veya perasetik asit oksidasyonu ve ultraviyole 1şınlama) koronavirüsü tam olarak etkisiz hale getiremediği bildirilmiştir (Kataki ve ark., 2021). Çin'de, COVID-19 sırasında hastane atıksuları için acil arıtma planında, hastanelerden gelen atıksuyun tam olarak dezenfekte edilmesi talimatı verilmiştir ve kalıntı klor seviyesi 6,5 ppm'in üzerine çıkarılmıştır (> 6,5 ppm klor dozu için temas süresi 90 dakikadan daha fazla belirlenirken; >10 ppm klor uygulandığında temas süresi 90 dakikadan az olarak belirlenmiştir) (Kataki ve ark., 2021). Çin Ekoloji ve Çevre Bakanlığı, tüm sektörlerin tarafindan yapılan yoğun dezenfeksiyon nedeniyle içme suyu kaynaklarında kalıntı klor tespit edildiği, ancak konsantrasyonların içme suyu kalite standardının $(0,3 \mathrm{mg} / \mathrm{L}$ ) altında olduğunu bildirmiștir (Kataki ve ark., 2021). Virüslerin giderimine ilişkin bilgiler, koronavirüslerin giderimi hakkında genel bir bilgi vermek için dikkatli bir şekilde kullanılabilir.

Bir çalışmada subtropikal koşullar altında aktif çamur arıtma prosesinin enterik virüslerin $3 \log$ üzerinde giderim sağladığı gözlemlenmiştir (Sidhu ve ark., 2018).

Wurtzer ark.'nın (2020), Paris'teki arıtma öncesi ve arıtma sonrasında atıksularda SARS-CoV-2 RNA tespit edilmiştir. Arıtma sonrasında atıksudaki viral yükün, arıtma öncesindeki atıksuya kıyasla 100 kat daha düşük olduğu görülmüştür. Ancak yapılan çalışmada, kullanılan atıksu arıtma proseslerinin türü veya bu viral partiküllerin durumu hakkında bilgi verilmemiştir. Arttılmış atıksuda tespit edilen viral RNA'nın, viral partikülün parçaları da olabileceği ifade edilmiştir. Bu nedenle bu bilgi, atıksu arıtımı sırasında koronavirüslerin olası giderimini anlamaya yardımcı olmak için yetersizdir. Atıksudaki azalmanın iki ana nedeni olarak ise viral adsorpsiyon ve inaktivasyon verilmiştir (Bibby ve ark., 2015).

Ye ve ark.'nın (2016), yaptıkları çalışmada fare hepatit virüsünün (FHV) insan koronavirüslerinin bir temsilcisi olarak kullanıldığı çalışmada, dengedeki atıksuda katı maddelere daha hızlı adsorbe olduğunu gözlemlemişlerdir. Ayrıca, FHV'nin $\% 26$ 'sının dengedeki atıksu katılarına adsorbe edileceğini ve \%99'unun ise 0,4-2,9 saatte oluşacağını tahmin etmişlerdir. Bu nedenle, Aktif çamur prosesleri sırasında koronavirüslerin en yüksek oranda gideriminin birincil arıtımda meydana gelebileceği ileri sürülmüştür.
Garcıa ve ark.'nın (2003) yapmış oldukları çalışmada, doygunluğa ulaşılıncaya kadar artan hidrolik bekletme süresi (HBS) ile mikrobiyal inaktivasyonun arttığı bildirilmiştir.

Verbyla ve Mihelcic (2015), yaptıkları çalışmada bir atıksu sisteminde her 14,5-20,9 günlük bekletme süresi aralığında virüslerde ortalama $1 \log$ azalma olduğunu bulmuşlardır. $\mathrm{Bu}$ nedenle, katılar üzerinde adsorpsiyona ek olarak, daha uzun bir HBS, atıksudaki koronavirüslerin inaktive edilmesinde de kritik olabileceği sonucuna varılmıştır.

Sonuç olarak, koronavirüsler katılara adsorbe edildiği için çamurda yüksek virüs konsantrasyonuna neden olacaktır. Ayrıca bu çalışmalardan yola çıkılarak, çamurdaki virüs birikiminin, bekletme süresi ile birlikte artacağı sonucuna varılabilir. Virüslerin giderimin de kullanılan arıtma yöntemleri detaylı olarak bu bölümde verilmiştir.

\subsection{Ozon Teknolojisi}

Ozon, yüksek klor ihtiyacı ve dezenfektan yan ürünleri sorunu nedeniyle, mahsullerin sulanmasında kullanılan atıksuların dezenfeksiyonunda ve yüzey suyuna deşarjlarda dezenfektan olarak klor yerine tercih edilmektedir (White, 1978). Birçok virüsün etkisiz hale getirilmesinde, etkili olan artıma yöntemlerinden biridir. Uluslararası Ozon Derneği (IOA) tarafından yapılan bir açıklamada, COVID-19 hakkında yapılan herhangi bir araştırma ve testten haberdar olmadıklarını, araştırmanın hakem değerlendirmesinin henüz tamamlanmamış olması nedeniyle COVID-19'un ozon ile inaktive olduğuna dair kesin sonuçlara varılamayacağ 1 ifade edilmiştir (Lesimple ve ark., 2020).

Perez-Rey ve ark.'nın (1995) tarafından yaptığı çalışmada; hayvanlar için aşı hazırlanmasında dört virüs, üç sporlanmamış bakteri, iki sporlanmış bakteri ve bir mantar içeren on farklı mikroorganizma türü kullanılmıştır. Çalışmada, virüslerin en kolay inaktive edilen mikroorganizmalar olduğu ve sporlanan bakteriler en dirençli suş olduğu bildirilmiş̧ir. İnaktivasyonun, hem ozon hem de mikroorganizma konsantrasyonuna bağlı olarak ikinci derece bir kinetiğe uygun olduğu belirlenmiştir. Çalışmada sonuç olarak, atıksudaki mikroorganizmaların tamamen inaktivasyonunun ozon uygulamasiyla mümkün olduğu ileri sürülmüştür.

\subsection{Membran Teknolojisi}

Membranları, gözenek boyutlarına ve dağılımlarına göre; ters ozmoz (TO), nanofiltrasyon (NF), ultrafiltrasyon (UF) ve mikrofiltrasyon (MF) olmak üzere dört kategoriye ayrılır (Lesimple ve ark., 2020). Atıksu arıtımında yaygın olarak kullanilan membran teknolojileri; ultrafiltrasyon $(0.005 \approx 10$ $\mu \mathrm{m})$ ve mikrofiltrasyon $(0.1-0.2 \mu \mathrm{m})$ dur. Ortalama $120 \mathrm{~nm}$ $(0,12 \mu \mathrm{m})$ viral partikül çapı ve $80 \mathrm{~nm}(0,08 \mu \mathrm{m})$ zarf çapına sahip olan koronavirüslerin UF membranları ya da daha düşük gözenek çaplı membranların (NF, TO) tercih edilmesi gerekmektedir (Neuman ve Buchmeier, 2016).

Goswani ve ark. (Goswami ve Pugazhenthi, 2020) çalışmalarında, polimerik ve seramik membranların sudan virüs giderimindeki etkisini araştırmışlardır. Rapor edilen aralık, 0,27 olduğundan giderme etkinliklerinin oldukça değişken olduğu ileri sürülmüştür.

Chaudhry ve ark.'nın (Chaudhry ve ark., 2015) yaptıkları çalışmada, $0.04 \mu \mathrm{m}$ 'lik bir membran tarafından tutulmanın, farklı virüs ve fajların $\% 50$ 'den fazla giderebileceğini 
bildirmiştir. Membran biyoreaktör (MBR) ile arıtım sırasında virüs türlerine göre viral uzaklaştırmanın 2 ila 3 log arasında değişmektedir (Amoah ve ark., 2020). MBR'larda viral veya diğer patojenlerin gideriminde ana mekanizma, tutma veya dışarda bırakma olduğu tespit edilmiştir (Amoah ve ar ., 2020).

\subsection{UV İnaktivasyonu ve Klorlama}

UV radyasyonu ve klorlama yaygın olarak kullanılan dezenfeksiyon işlemleri arasında yer almaktadır (Bhatt ve ark., 2020). Bu konuda yapılan çalışmalarda, üçüncül atıksu arıtma prosesleri, örneğin klorlama ve UV arıtımı ile atıksuda kalan koronavirüslerin uzaklaştırılmasını sağlayabileceği ileri sürülmüştür (Amoah ve ark., 2020). Wang ve ark.'nın (2005), SARSCoV'un $20 \mathrm{mg} / \mathrm{L}$ klor ile 1 dakikada tamamen inaktive edilebileceğini tespit etmişlerdir. Ayrıca, klor dioksitin inaktivasyonda daha az etkili olduğunu gözlemlemişlerdir. SARS-CoV, serbest klor ile karşılaştırıldığında, diğer virüsler içinde benzer sonuçlar rapor edildiği görülmüştür (Wati ve ark., 2018; Young ve ark, 2020). Klorun, virüslerin kapsid protein omurgasının bölünmesi yoluyla virüsleri inaktive ettiği, bu nedenle konakçı hücrelere viral genom enjeksiyonunu inhibe ettiği bildirilmiştir (Wigginton ve ark., 2012). Birkaç çalışma da UV 1şıması kullanılarak koronavirüslerin inaktivasyonu bildirilmiştir (Wang ve ark., 2005; Casanova ve ark., 2009). Koronavirüsler gibi zarflı virüslerin, zarfsız virüslere göre UV'ye karşı daha duyarlı olduğu bildirilmiştir (Pinon ve Vialette, 2018). UV'nin koronavirüsleri inaktive ettiği ana mekanizmanın ise, nükleik asite zarar veren pirimidin dimerlerinin üretilmesinin olabileceği ifade edilmiştir (Smith ve Denison, 2013).

Qiu ve ark.'nın (2018), iki tam ölçekli belediye AAT'de insan bulaşıcı enterik virüslerinin UV ile arıtma öncesi ve sonrası virüs türlerindeki değişimini qPCR kullanarak değerlendirmişlerdir. Çalışmada, sonuç olarak enfeksiyöz reovirüs için ortalama log azalma tahminleri, iki AAT için 1,2 ve 1,8 log olarak bulunmuştur. Kolifaj ve E. coli üzerinde 2,5-3'e kadar log azalma tespit edilmiştir (Qiu vd., 2018).

Simhon ve ark.'nın (2019), UV ışığının ve klorun farklı virüslerin dezenfeksiyonunda kullanılabileceğini bildirmişlerdir. Kolifaj ve E. coli azalmasının normalde 0,3 ila 1,3 log aralığında iken UV ve klorun kullanılması sonucunda 2,5-3 log azalma elde edildiği görülmüştür. Üstelik kum filtre uygulanan numunelere göre sonuçların daha iyi olduğunu gözlemlenmiştir. Ancak UV inaktivasyonu ve hipoklorit ile muamelede virüsler inaktif hale getirilirken, oksidasyon süreçleri yoluyla makinelere zarar verilebilir.

Christensen ve Myrmel (2018) çalışmalarında, üç farklı koagülant (zirkonyum, kitosan ve polialuminyum klorür) kullanarak koagülasyon-filtrasyon sisteminin virüs giderimindeki (Hepatis A virüs, bovine norovirüs ve MS2) etkinliğini test etmişlerdir. Flokülasyon ve filtrasyonun kombinasyonunun; virüs türüne, yumak oluşumuna ve doğal organik maddenin varlığına bağlı olarak viral mevcudiyette giderimin \%10'dan \%70'e çıktığı belirlenmiştir. Bovine norovirüste, üç koagülantın hepsinde seyreltilmemiş suda, seyreltilmiş suya göre daha fazla azaldığı tespit edilmiştir (ortalama $4 \mathrm{log}$ ). Bu son örnekte, kitosan en etkili koagülant olarak belirlenmiştir.

Bir diğer çalışmada; SARS-CoV ve faj f2'nin farklı klor çözeltilerine karşı direncini belirlemek için $100 \mathrm{ml}$ evsel atıksuya bu virüsler aşılanmıştır. 30 dakikalık bir dezenfeksiyon deneyi sirasında, SARS-CoV $10 \mathrm{mg} / \mathrm{L}$ klor veya $20 \mathrm{mg} / \mathrm{L}$ klor dioksit ile tamamen inaktive edildiği görülmüştür. Ancak faj f2 $40 \mathrm{mg} / \mathrm{L}$ klor konsantrasyonu uygulanmasına rağmen tamamen inaktive edilmediği saptanmıştır (Wang ve ark., 2005).

Zhang ve ark.'nın (2020) yaptıkları çalışmada, Çin'de bulunan Wuchang Fangcang Hastanesinde 5 Şubat-10 Mart 2020 arasında, 1124 COVID-19 hastasının kullanması için 8 ayrı tuvalet ve duşlardan gelen atıksu kanalizasyonda birleştirilmiş olup 4 farklı ön dezenfeksiyon tankında dezenfekte edilmiştir. 26 Şubat-1 Mart 2020 tarihleri arasında atıksu >0,5 mg/L sodyum hipoklorit 1,5 saatlik dezenfeksiyondan sonra SARS-CoV-2 viral RNA varlığı tespit edilmiş ve $800 \mathrm{~g} / \mathrm{m}^{3}$ 'ün tamamen giderilmesi için etkili olmadığı belirlenmiştir. Ancak, 6-10 Mart 2020 tarihinde sodyum hipoklorit dozu $6700 \mathrm{~g} / \mathrm{m}^{3}$ 'e çıkarıldığında SARS-CoV-2'nin tamamen deaktivasyonunun sağlandığ görülmüştür. $\mathrm{Bu}$ dezenfeksiyon işleminin sonunda yüksek bir dezenfeksiyon yan ürün kalıntısı oluşmaktadır. Sonuç olarak, ekolojik riskleri daha iyi değerlendirmek için daha fazla çalışma yapılması gerektiği vurgulamışlardır.

\section{Türkiye'deki Atıksu Arıtma Tesislerinin Mevcut Durumu}

Tarım ve Orman Bakanlığı Su Yönetimi Genel Müdürlüğü tarafindan içme suyu, atıksu ve kanalizasyon şebekesinde ortaya çıkabilecek yeni tip koronavirüs COVID-19 riskine karşı bir rapor hazırlanmıştır. Rapora göre Türkiye'de debisi 2.000 $\mathrm{m}^{3}$ /gün'ün üzerinde olan 603 evsel AAT olduğu ve bu tesislerin toplam debisinin 16,7 milyon $\mathrm{m}^{3}$ /gün olduğu belirtilmiştir. 603 evsel AAT'nin 221'inden çıkan arıtılmış kullanılmış suların fiili olarak tarımsal sulamada kullanıldığ 1 ve AAT toplam debisi 6,7 milyon $\mathrm{m}^{3}$ /gün olarak verilmiştir. $\mathrm{Bu} A \mathrm{AAT}$ 'lerden çıkan fiilen kullanılmış sularla; tahıl, sebze, meyve, narenciye, pamuk, zeytin, susam, mısır vb. pek çok ürünün sulandığı belirtilmiştir. Ayrıca 92 AAT çıkış suları ile çiğ tüketilen sebzelerin de olduğu belirtilmiştir (TOBSYGM, 2020).

Ülkemizde 50 AAT çıkış sularını barajlara deşarj etmektedir. $\mathrm{Bu}$ barajlar genel olarak sulama suyu amaçlı kullanılmaktadır. Raporda, 603 AAT'nin sadece 53'ünde dezenfeksiyon ünitesi bulunduğu, fiilen sulamada kullanılan 221 tesisten, 42'sinde dezenfeksiyon ünitesi olduğu ve 42 dezenfeksiyon ünitesinden de sadece 13'ünün çalıştırıldığı vurgulanmıştır. Ayrıca dezenfeksiyon ünitesi çalıştırılan 4 tesisin çıkış sularından alınan numunelere yapılan analizler sonucunda mikrobiyolojik olarak sulama suyu kalite kriterlerini sağlamadığ (TOBSYGM, 2020). İyi bir şekilde dezenfekte edilmemiş kullanılmış (arıtılmış) sular, çiğ olarak tüketilen sebzelerin sulanmasında kullanılması durumunda bakteriler ve virüsler gibi patojenik mikroorganizmalarla bu gıdaları kontamine edebilmektedir (Bağcı ve ark., 2008). Kontamine olan çiğ sebzelerde bulunan bazı patojen mikroorganizmaların ishal, dizanteri yersiniozis ve listeriozis gibi sağlık sorunlarına hatta önemli hastalıklara neden olabilir. $\mathrm{Bu}$ nedenle tesislerin dezenfeksiyon üniteleri aktif hale getirilmeli ve çıkış sularının analizleri yapılarak sulama suyu kriterlerine mikrobiyolojik açıdan uygun hale getirilmelidir (Pingulkar ve ark., 2001).

\section{Sonuç}

COVID-19 hastalığı solunum ve temas yoluyla insanların SARS CoV 2 ile enfekte olması sonucunda oluşan bir hastalıktır. $\mathrm{Bu}$ virüs dünyada yapılan araştırmalar sonunda bazı şehirlerin atıksularında tespit edilmiştir. Ancak, virüsün su ya da atıksu 
yoluyla bulaştığına dair bir kanıt yoktur. Fakat laboratuvar testlerinde, 10 güne kadar musluk suyunda ve 100 güne kadar atıksuda canlı kalabildiği bulunmuştur. Koronavirüsler, suyla bulaşan hastalıklara yol açan virüslerle karşılaştırıldığında sucul ortamda etkinliğini çok daha hızlı kaybederler. Ayrıca koronavirüsler klor, ozon, UV vb. dezenfektanlar ile yapısı bozularak inhibe olmaktadır. $\mathrm{Bu}$ nedenle mevcut AAT'lerden virüslerin giderilmesinde dezenfeksiyon ünitelerinin rolü büyüktür.

Dünyada, küresel COVID-19 salgını bağlamında, halk ve çevre için sağlık risklerini azaltmak büyük önem taşımaktadır. Atıkların ve atıksuların uygun arıtımı yapılmaz ise halk enfeksiyon tehlikesine maruz kalabilir. $\mathrm{Bu}$ bağlamda, virüs içeren arıtılmış veya ham atıksular, arıtma çamurları, suyun tekrar kullanımı ve alıcı su ortamlarına deşarj edilmesi ikincil bulaşmaya neden olabileceği göz ardı edilmemelidir. Koronavirüs vaka sayısının yoğun olduğu şehirlerde virüsün ikincil yayılımını önlemek için atıksuyun sulama ve temizlik gibi yeniden kullanımının azaltılması veya yasaklaması hükümetler tarafından yapılabilir. Entegre halk sağlığı politikasının bir parçası olarak, kanalizasyon sistemlerinde taşınan atıksular iyi tasarlanmış ve iyi yönetilen merkezi AAT'lerde arıtılmalıdır. AAT'lerin her bir ünitesi virüslerin ve diğer zararlı mikroorganizmaların kademeli olarak giderimi yapılmaktadır. Ancak sadece AAT'lerin tam verimde ve projelendirildiği şekilde çalıştığı durum da virüslerin de giderimi sağlanabilir. Çıkış sularına yapılacak analizler ile çıkış suyu kalitesi düzenli olarak takip edilmelidir. Mevcut AAT çıkış sularının, AKM dolayısıyla virüs içerebileceği göz ardı edilmemelidir. $\mathrm{Bu}$ nedenle, ikincil arıtım yapılmadan kullanılmamalıdır.

Atıksudaki koronavirüslerin varlığı hakkındaki bilgi, koronavirüslere odaklanan önceki çevresel araştırmaların eksikliğinden dolayı büyük ölçüde sınırlıdır. Koronavirüsler, fekal-oral yoldan ziyade kişiden kişiye temasla yayıldığ düşünülen zarflı bir virüs olduğu için dışkıdaki varlığı daha detaylı araştırma gerektirmektedir. Virüsün çevreye yayılımını azaltmakta oldukça önemlidir. Bu nedenle, insanlara yapılan koronavirüs testinde olduğu gibi, koronavirüs yüzey sularında, yeraltı sularında, musluk suyunda, atıksularda, kanalizasyon çamurunda, ayrıca balık ve suda yaşayan kabuklu deniz ürünleri içinde analizler yapılmalıdır (Medema ve ark., 2020).

AAT'lerde, Atıksu Bazlı Epidemiyoloji planının geliştirilmesi yoluyla atıksudaki viral RNA'nın varlığı belirlenerek bir bölgedeki hastalığın erken teşhisi için bir çözüm olabilir. COVID-19 virüsünün su ve atıksulardan yüksek verimde giderimi için; birincil, ikincil ve ileri (ozon, UV gibi) arıtma yöntemleri birlikte kullanılabilir. Ancak bu konuda yapılan çalışma sayısı azdır. $\mathrm{Bu}$ nedenle, koronavirüslerin atıksulardan ve sulardan giderimi için daha fazla araştırma yapılmalı, ekonomik, yüksek arıtma verimine sahip, ikincil kirliliğe neden olmayan ve çevre dostu arıtma yöntemleri geliştirilmelidir.

\section{Kaynakça}

Ağdıç, O., Kayacan, S., Dertli, E., Arıcı, M., (2020). Gıda Güvenliği Açısından COVID-19 Etmeni SARS-CoV-2'nin Değerlendirilmesi ve Korunma Yöntemleri. Avrupa Bilim ve Teknoloji Dergisi, (18), 927-933.

Ahmed, W., Angel, N., Edson, J., Bibby, K., Bivins, A., O'Brien, J.W., Choi, P.M., Kitajima, M., Simpson, S.L., Li, J.,
Tscharke, B., Verhagen, R., Smith, W.J.M., Zaugg, J., Dierens, L., Hugenholtz, P., Thomas, K.V., Mueller, J.F. (2020). First confirmed detection of SARS-CoV-2 in untreated wastewater in Australia: A proof of concept for the wastewater surveillance of COVID-19 in the community. Science of The Total Environment, 728(August).

Ak, Ö. (2020). Küresel Kabus, Bilim Teknik Dergisi, Mart say1s1.

Aka Biyoteknoloji. Koronavirüsün yapıs1. https://akabiotech.com/sars-cov-2-yapisi-ve-enfeksiyon mekanizmasi-hakkinda/. (Erişim tarihi: 20.09. 2020).

Alpaslan Kocamemi, B., Kurt, H., Sait, A., Sarac, F., Saatci, A. M., Pakdemirli, B. (2020). SARS-CoV-2 Detection in Istanbul Wastewater Treatment Plant Sludges. medRxiv.org the preprint server for Health Sciences, January.

Amoah, I. D., Kumari, S., Bux, F. (2020). Coronaviruses in wastewater processes: Source, fate and potential risks. Environment International, 143(May).

Arbely, E., Granot, Z., Kass, I., Orly, J., Arkin, I. T. (2006). A trimerizing GxxxG Motif is uniquely inserted in the severe acute respiratory syndrome (SARS) coronavirus spike protein transmembrane domain. Biochemistry, 45(38), 11349-11356.

Bağc1, A., Özmen, Toğay, U., Temiz, S. 82008). Çiğ Tüketilen Sebzelere Uygulanan Yüzey Dekontaminasyon Yöntemleri. Türkiye 10. Gida Kongresi, Erzurum-Türkiye, 173-176, 21 23 Mayis.

Balboa, S., Mauricio-Iglesias, M., Rodriguez, S., MartínezLamas, L., Vasallo, F.J., Regueiro, B., Lema, J.M. (2020). The fate of SARS-CoV-2 in wastewater treatment plants points out the sludge line as a suitable spot for incidence monitoring. medRxiv.org-the preprint server for Health Sciences, January.

Bhatt, A., Arora, P., Prajapati, S. K. (2020). Occurrence, fates and potential treatment approaches for removal of viruses from wastewater: A review with emphasis on SARS-CoV-2. Journal of Environmental Chemical Engineering, 8(5), 104429, October.

Bibby, K., Fischer, R. J., Casson, L. W., Stachler, E., Haas, C. N., Munster, V. J. (2015). Persistence of Ebola Virus in Sterilized Wastewater. Environmental Science \& Technology Letters, 2(9), 245-249.

Bibby, K., Peccia, J. (2013). Identification of Viral Pathogen Diversity in Sewage Sludge by Metagenome Analysis. Environmental Science \& Technology, 47(4), 1945-1951.

Blanco, A., Abid, I., Al-Otaibi, N., Pérez-Rodríguez, F. J. (2019). Glass Wool Concentration Optimization for the Detection of Enveloped and Non-enveloped Waterborne Viruses. Food and Environmental Virology, 11(2), 184-192.

Bogler, A., Packman, A., Furman, A., Gross, A., Kushmaro, A., Ronen, A., Dagot, C., Hill, C., Vaizel-Ohayon, D., Morgenroth, E., Bertuzzo, E., Wells, G., Kiperwas, H. R., Horn, H., Negev, I., Zucker, I., Bar-Or, I., Moran-Gilad, J., Balcazar, J. L., Bar-Zeev, E. (2020). Rethinking wastewater risks and monitoring in light of the COVID-19 pandemic. In Nature Sustainability, 3(12), 1-10.

Chen, J. (2020). Pathogenicity and transmissibility of 2019nCoV-A quick overview and comparison with other emerging viruses. Microbes Infection, 22 (2), 69-71.

CDC (Centers of Disease Control and Prevention). (2020). How Coronavirus Spreads. https://www.cdc.gov/coronavirus. (Erişim tarihi: 5.09.2020). 
Casanova, L., Rutala, W. A., Weber, D. J., Sobsey, M. D. (2009). Survival of surrogate coronaviruses in water. Water Research, 43(7), 1893-1898.

Chan, K.H., Poon, L.L., Cheng, V.C.C., Guan, Y., Hung, I.F.N., Kong, J., Yam, L.Y., Seto, W.H., Yuen, K.Y., Peiris, J.S.M. (2004). Detection of SARS Coronavirus in Patients with Suspected SARS. Emerging Infectious Diseases, 10(2), 294.

Chaudhry, R. M., Nelson, K. L., Drewes, J. E. (2015). Mechanisms of Pathogenic Virus Removal in a Full-Scale Membrane Bioreactor. Environmental Science \& Technology, 49(5), 2815-2822.

Christensen, E., Myrmel, M. (2018). Coagulant residues influence on virus enumeration as shown in a study on virus removal using aluminium, zirconium and chitosan. Journal of Water Health, 16(4), 600-613.

Council Environment Protection and Heritage (CDC). (2020). National Guidelines for Water Recycling: Managing Health and Environmental Risks. https://www.susana.org/en/knowledge-hub/resources-andpublications/library/details (Erişim tarihi: 20.09.2020).

Çevre Mühendisleri Odası İstanbul Şubesi (ÇMO). (2020). Su ve Atıksu Yönetiminde Covid-19 Etkisi Değerlendirilmesi. http://www.cmo.org.tr/resimler/ekler/9e9b26cc1a4d919_ek. pdf?tipi=78\&turu=H\&sube=2. (Erişim tarihi: 11.12.2020).

Duman, H. (2017). Arıtılmış Kentsel Atıksuların Sulamada Yeniden Kullanımı: Kayseri Atıksu Arıtma Tesisi Örneği. Uzmanlık Tezi, Orman ve Su İşleri Bakanlığı, Ankara.

Dias, E., Ebdon, J., Taylor, H., (2018). The application of bacteriophages as novel indicators of viral pathogens in wastewater treatment systems. Water Research, 129, 172179.

Droste, R. L., Gehr, R. L. (2018). Theory and practice of water and wastewater treatment, John Wiley \& Sons.

Fumian, T. M., Leite, J. P. G., Castello, A. A., Gaggero, A., Caillou, M. S. L. d., Miagostovich, M. P. (2010). Detection of rotavirus A in sewage samples using multiplex qPCR and an evaluation of the ultracentrifugation and adsorptionelution methods for virus concentration. Journal of Virological Methods, 170(1-2), 42-46.

Garcia, J., Vivar, J., Aromir, M., Mujeriego, R. (2003). Role of hydraulic retention time and granular medium in microbial removal in tertiary treatment reed beds. Water Research, 37(11), 2645-2653.

Gawlik, H. f. f., Martinsohn, B. M. H., de Santi, G. (2020). Supply security for critical chemicals needed for water supply and sanitation during COVID-19-Crisis. https://www.envir.ee/sites/default/files/Vesi/uhisveevark_ka nalisatsioon/jrc_report_critical_chemicals_for_water_supply _and_sanitation.pdf. (Erişim tarihi: 28.08.2020).

Gerba, C. P., Betancourt, W. Q., Kitajima, M. (2017). How much reduction of virus is needed for recycled water: A continuous changing need for assessment?. Water Research, 108(January), 25-31.

Gundy, P. M., Gerba, C. P., Pepper, I. L. (2009). Survival of Coronaviruses in Water and Wastewater. Food and Environmental Virology, 1(1), 10.

Goswami, K. P., Pugazhenthi, G. (2020). Credibility of polymeric and ceramic membrane filtration in the removal of bacteria and virus from water: A review. Journal of Environmental Management, 268.

Green, H., Wilder, M., Middleton, F.A., Collins, M., Fenty, A., Gentile, K., Kmush, B., Zeng, T., Larsen, D.A. (2020). Quantification of SARS-CoV-2 and cross-assembly phage
(crAssphage) from wastewater to monitor coronavirus transmission within communities. medRxiv.org-the preprint server for Health Sciences, January.

Haramoto, E., Kitajima, M., Katayama, H., Ito, T., Ohgaki, S. (2009). Development of virus concentration methods for detection of koi herpesvirus in water, Journal of Fish Diseases. 32(3), 297-300.

Kampf, G., Todt, D., Pfaender, S., Steinmann, E. (2020). Persistence of coronaviruses on inanimate surfaces and their inactivation with biocidal agents. Journal of Hospital Infection, 104(3), 246-251.

Kataki, S., Chatterjee, S., Vairale, M. G., Sharma, S., Dwivedi, S. K. (2021). Concerns and strategies for wastewater treatment during COVID-19 pandemic to stop plausible transmission. Resources, Conservation \& Recycling, 164.

Katayama, H., Haramoto, E., Oguma, K., Yamashita, H., Tajima, A., Nakajima, H., Ohgaki, S. (2008). One-year monthly quantitative survey of noroviruses, enteroviruses, and adenoviruses in wastewater collected from six plants in Japan. Water Research, 42(6-7), 1441-1448.

Kitajima, M., Iker, B. C., Pepper, I. L., Gerba, C. P. (2014). Relative abundance and treatment reduction of viruses during wastewater treatment processes - Identification of potential viral indicators. Science of The Total Environment, 488-489, 290-296.

Keegan, A. R., Robinson, B., Monis, P., Biebrick, M., Liston, C. (2013). Validation of activated sludge plant performance for virus and protozoan reduction. Journal Water Reuse Desalination, 3(2), 140-147.

La Rosa G. ve ark., 2020. First Detection of SARS-COV-2 in Untreated Wastewaters in Italy, medRxiv.org - the preprint server for Health Sciences, January.

Lesimple, A., Jasim, S. Y., Johnson, D. J., Hilal, N. (2020). The role of wastewater treatment plants as tools for SARS-CoV2 early detection and removal. Journal of Water Process Engineering, 38.

Lodder, W., de Roda Husman, A. M. (2020). SARS-CoV-2 in wastewater: potential health risk, but also data source. Lancet Gastroenterology Hepatology. 5(6), 533-534.

Lu, G., Wang, Q., Gao, G. F. (2015). Bat-to-human: spike features determining 'host jump' of coronaviruses SARSCoV, MERS-CoV, and beyond. Trends Microbiology, 23(8), 468-478.

Medema, G., Heijnen, L., Elsinga, G., Italiaander, R., Brouwer , A. (2020). Presence of SARS-Coronavirus-2 in sewage. Environmental Science and Tecnology Letters, 7(7), 511516.

McLennan, S. D., Peterson, L. A., Rose, J. B. (2009). Comparison of Point-of-Use Technologies for Emergency Disinfection of Sewage-Contaminated Drinking Water. Applied Environmental Microbiology, 75(22), 7283 LP 7286.

Neuman, B. W., Buchmeier, M. J. (2016). Supramolecular Architecture of the Coronavirus Particle. Advances in Virus Research, 96, 1-27.

Nemudryi, A., Nemudraia, A., Surya, K., Wiegand, T., Buyukyoruk, M., Wilkinson, R., Wiedenheft, B. (20209. Temporal detection and phylogenetic assessment of SARS$\mathrm{CoV}-2$ in municipal wastewater. medRxiv.org-the preprint server for Health Sciences, January. 
Noble, R. T., Fuhrman, J. A. (1997). Virus decay and its causes in coastal waters, Applied and Environmental Microbiology. 63(1), 77-83.

Nordgren, J., Matussek, A., Mattsson, A., Svensson, L., Lindgren, P.-E., (2009). Prevalence of norovirus and factors influencing virus concentrations during one year in a fullscale wastewater treatment plant. Water Research, 43(4), 1117-1122.

Or, I.B., Yaniv, K., Shagan, M., Ozer, E., Erster, O., Mendelson, E., Mannasse, B., Shirazi, R., Kramarsky-Winter, E., Nir, O., Abu-Ali, H. (2020). Regressing SARS-CoV-2 sewage measurements onto COVID-19 burden in the population: a proof-of-concept for quantitative environmental surveillance. medRxiv.org-the preprint server for Health Sciences, January.

Peccia, J., Zulli, A., Brackney, D.E., Grubaugh, N.D., Kaplan, E.H., Casanovas-Massana, A., Ko, A.I., Malik, A.A., Wang, D., Wang, M., Weinberger, D.M., J. (2020). SARS-CoV-2 RNA concentrations in primary municipal sewage sludge as a leading indicator of COVID-19 outbreak Dynamics. medRxiv.org-the preprint server for Health Sciences, January.

Perez-Rey, C. B. R., Chaez, H. (1995). Ozone inactivation of biologically-risky wastewaters. Ozone: Science \& Engineering, 17(5), 499-509.

Petrosillo, N., Viceconte, G., Ergonul, O., Ippolito, G., Petersen, E. (2020). COVID-19, SARS and MERS: are they closely related?. Clinical Microbiology and Infection, 26(6), 729734.

Pingulkar, K., Kamat, A., Bongirwar, D. (2001). Microbiological quality of fresh leafy vegetables, salad components and ready-to-eat salads: an evidence of inhibition of Listeria monocytogenes in tomatoes. International Journal of Food Sciences and Nutrition, 52(1), 15-23, January.

Pinon, A., Vialette, M. (2018). Survival of Viruses in Water. Intervirology, 61(5), 214-222.

Qiu, Y., Li, Q., Lee, B., Ruecker, N., Neumann, N., Ashbolt, N., Pang, X. (2018). UV inactivation of human infectious viruses at two full-scale wastewater treatment plants in Canada. Water Research, 147, 73-81.

Randazzo, W., Truchado, P., Cuevas-Ferrando, E., Simón, P., Allende, A., Sánchez, G. (2020). SARS-CoV-2 RNA in wastewater anticipated COVID-19 occurrence in a low prevalence area. Water Research, 181, 115942, August.

Rimoldi, S.G., Stefani, F., Gigantiello, A., Polesello, S., Comandatore, F., Mileto, D., Maresca, M., Longobardi, C., Mancon, A., Romeri, F., Pagani, C. (2020). Presence and vitality of SARS-CoV-2 virus in wastewaters and rivers. medRxiv.org-the preprint server for Health Sciences, January.

Shereen, M. A., Khan, S., Kazmi, A., Bashir, N., Siddique, R., (2020). COVID-19 infection: Origin, transmission, and characteristics of human coronaviruses. Journal of Advanced Research, 24, 91-98.

Sidhu, J. P. S., Sena, K., Hodgers, L., Palmer, A., Toze, S. (2018). Comparative enteric viruses and coliphage removal during wastewater treatment processes in a sub-tropical environment. Science of The Total Environment, 616-617, 669-677.

Simhon, A., Pileggi, V., Flemming, C. A., Bicudo, J. R., Lai, G., Manoharan, M. (2019). Enteric viruses in municipal wastewater effluent before and after disinfection with chlorine and ultraviolet light. Journal of Water Health, 17(5), 670-682.

Sinton, L. W., Hall, C. H., Lynch, P. A., Davies-Colley, R. J. (2002). Sunlight Inactivation of Fecal Indicator Bacteria and Bacteriophages from Waste Stabilization Pond Effluent in Fresh and Saline Waters. Applied and Environmental Microbiology, 68(3), 1122 - 1131.

Smith, E. C., Denison, M. R. (2013). Coronaviruses as DNA Wannabes: A New Model for the Regulation of RNA Virus Replication Fidelity. PLOS Pathoglogy, 9(12), December, e1003760.

Tarım ve Orman Bakanlığı Su Yönetimi Genel Müdürlüğü (TOBSYGM). (2020). Kovid-19 (SARS-CoV-2) Virüsünün Bulaşma Riskinin Kullanılmış Suların Yeniden Kullanılması Perspektifinden Değerlendirilmesi Raporu. Ankara. https://www.tarimorman.gov.tr/SYGM/Belgeler/covid\%2019\%20arde\%20duyuru/KS_Covid_19_Raporu.pdf

Verbyla, M. E., Mihelcic, J. R. (2015). A review of virus removal in wastewater treatment pond systems. Water Research, 71, 107-124.

Wang, X.W., Li, J., Guo, T., Zhen, B., Kong, Q., Yi, B., Li, Z., Song, N., Jin, M., Xiao, W., Zhu, X. (2005). Concentration and detection of SARS coronavirus in sewage from Xiao Tang Shan Hospital and the 309th Hospital. Journal of Virology Methods, 128(1), 156-161.

Wang, X.W.1, Li, J.S., Guo, T.K., Zhen, B., Kong, Q.X., Yi, B., Li, Z., Song, N., Jin, M., Wu, X.M., Xiao, W.J., Zhu, X.M., Gu, C.Q., Yin, J., Wei, W., Yao, W., Liu, C., Li, J.F., Ou, G.R., Wang, M.N., Fang ,T.Y., Wang, G.J., Qiu, Y.H., Wu, H.H., Chao, F.H., Li, J.W. (2005). Excretion and detection of SARS coronavirus and its nucleic acid from digestive system. World Journal of Gastroenterology, 11(28), 43904395.

Wang, D., Hu, B., Hu, C., Zhu, F., Liu, X., Zhang, J., Wang, B., Xiang, H., Cheng, Z., Xiong, Y., Zhao, Y. (2020). Clinical Characteristics of 138 Hospitalized Patients With 2019 Novel Coronavirus-Infected Pneumonia in Wuhan, China. JAMA, 323(11), 1061-1069.

Wati, S., Robinson, B. S., Mieog, J., Blackbeard, J., Keegan, A. R. (2018). Chlorine inactivation of coxsackievirus B5 in recycled water destined for non-potable reuse. Journal of Water and Health, 17(1), 124-136.

WEF (Water and Environment Federation). (2020). Current Priority: Coronavirus. https://www.wef.org/newshub/current-priorities/coronavirus/. (Erişim tarihi: 18.09.2020).

White, G.C. (1978). Disinfection of Wastewater and Water for Reuse, Van Nostra.

WHO (World Health World Health Organization), FAO (Food and Agriculture Organization of United Nations). (2020). Viruses in food:scientific advice to support risk management activities: meeting report. https://apps.who.int/iris/handle/10665/44030. (Erişim tarihi: 18.12.2020).

WHO (World Health World Health Organization). (2020). Water, sanitation, hygiene, and waste management for SARS-CoV2, the virus that causes COVID-19 Interim guidance Water, sanitation, hygiene, and waste management for the COVID19 virus: interim guidance. https://apps.who.int/iris/bitstream/handle/10665/331846/W HO-2019-nCoV-IPC_WASH-2020.3eng.pdf? sequence $=1 \&$ isAllowed $=$ y. $\quad$ (Erişim tarihi: 29.07.2020) 
Wigginton, K. R., Pecson, B. M., Sigstam, T., Bosshard, F., Kohn, T. (2012). Virus Inactivation Mechanisms: Impact of Disinfectants on Virus Function and Structural Integrity. Environmental Science \& Technology, 46(21), 1206912078.

Wu, F., Xiao, A., Zhang, J., Gu, X., Lee, W.L., Kauffman, K., Hanage, W., Matus, M., Ghaeli, N., Endo, N., Duvalet, C., Moniz, K., Erickson, T., Chai, P. (2020). SARS-CoV-2 titers inwastewater are higher than expected fromclinically confirmed cases. Applied and Environmental Science, 5(4), $1-9$.

Wong, M. V. M., Hashsham, S. A., Gulari, E., Rouillard, J.-M., Aw, T. G., Rose, J. B. (2013). Detection and characterization of human pathogenic viruses circulating in community wastewater using multi target microarrays and polymerase chain reaction. Journal Water Health, 11(4), 659-670.

Wurtzer, S., Marechal, V., Mouchel, J.-M., Moulin, L. (2020). Time course quantitative detection of SARS-CoV-2 in Parisian wastewaters correlates with COVID-19 confirmed cases. medRxiv.org - the preprint server for Health Sciences, January.

Xagoraraki, I., Brien, E. O. (2020.) Wastewater-Based Epidemiology for Early Detection of Viral Outbreaks, in Women in Water Quality: Investigations by Prominent Female Engineers. Springer International Publishing, 75-97.

Xu, D., Zhang, Z., Jin, L., Chu, F., Mao, Y., Wang, H., Liu, M., Wang, M., Zhang, L., Gao, G.F., Wang, F.S. (2005). Persistent shedding of viable SARS-CoV in urine and stool of SARS patients during the convalescent phase. European Journal of Clinical Microbiology \& Infectious Diseases, 24(3), 165-171.

Ye, Y., Ellenberg, R. M., Graham, K. E., Wigginton, K. R. (2016). Survivability, Partitioning, and Recovery of Enveloped Viruses in Untreated Municipal Wastewater. Environmental Science Technology, 50(10), 5077-5085.

Young, S., Torrey, J., Bachmann, V., Kohn, T. (2020). Relationship Between Inactivation and Genome Damage of Human Enteroviruses Upon Treatment by UV254, Free Chlorine, and Ozone. Food and Environmental Virology, 12(1), 20-27.

Zhang, Y., Chen, C., Zhu, S., Shu, C., Wang, D., Song, J., Song, Y., Zhen, W., Zijian, F., Wu, I.D. Amoah, Y. (2020). Isolation of 2019-nCoV from a Stool Specimen of a Laboratory-Confirmed Case of the Coronavirus Disease 2019 (COVID-19). China CDC Weekly, 2(8), 123-124.

Zhang, D., Ling, H., Huang, X., Li, J. (2020). Potential spreading risks and disinfection challenges of medical wastewater by the presence of Severe Acute Respiratory Syndrome Coronavirus 2 (SARS-CoV-2) viral RNA in septic tanks of fangcang hospital. Science of the Total Environment, (741), November. 